\title{
The effects of various temperature-salinity combinations on the body form of newly hatched Cyprinodon macularius (Teleostei)
}

\author{
John G. Sweet and OTto Kinne \\ Department of Zoology, University of Toronto, Canada and \\ Biologische Anstalt Helgoland, Zentrale, Hamburg-Altona
}

\begin{abstract}
KURZFASSUNG: Die Wirkungen verschiedener Temperatur-Salzgehalts Kombinationen auf die Körperform frischgeschlüpfter Cyprinodon macularius (Teleostei). Eier des Knochenfisches Cyprinodon macularius wurden 4 Stunden nach dem Laichakt in verschiedene TemperaturSalzgehalts Kombinationen überführt und unter kontrollierten Bedingungen erbrütet. Alle zum Laichen angesetzten Elterntiere besaßen einen ähnlichen genetischen Hintergrund (Nachkommen eines einzigen Ausgangspaares) und waren während ihres ganzen Lebens bei $28^{\circ} \mathrm{C}$ und $35 \%$ S gehalten worden. Die frischgeschlüpften Jungfische wurden möglichst rasch fixiert und 13 ihrer Körperdimensionen vermessen. - Alle vermessenen Dimensionen werden durch Temperatur und Salzgehalt des Inkubationsmediums beeinflußt. Trägt man die Dimensionen gegen die Inkubationstemperatur auf, so ergeben sich in den drei Testsalzgehalten unterschiedliche Kurvenzüge. In Süßwasser nimmt die Körperlänge von $28^{\circ}$ bis $33^{\circ} \mathrm{C}$ zu, verringert sich aber merkbar bei $34^{\circ} \mathrm{C}$; Körpertiefe und -breite verhalten sich praktisch umgekehrt; die größte Länge wird also bei einer intermediären Temperaturstufe erreicht und ist korreliert mit Minimalwerten für Tiefe und Breite ( $\mathrm{v}$-förmige Kurven); die größte Tiefe und Breite wird in den niedrigsten $\left(28^{\circ} \mathrm{C}\right)$ und in den höchsten $\left(34^{\circ} \mathrm{C}\right)$ Testtemperaturen erreicht. In $35 \%$ verringert sich die Körperlänge mit abnehmender Temperatur und sowohl die Tiefe als auch die Breite des Körpers verändern sich nahezu direkt proportional (weitgehend isometrisches Wadhstum). In $70 \%$ nimmt die Körperlänge von $26^{\circ}$ nach $28^{\circ} \mathrm{C}$ rapide ab, zeigr aber bei $31^{\circ} \mathrm{C}$ nur geringfügige Veränderungen; Tiefe und Breite verändern sich harmonisch; das Ausmaß der Isometrie ist jedoch zumeist geringer als in $35 \%$. Mit abnehmendem Salzgehalt verringert sich der Oberflächen/Volumen-Quotient des Körpers. Die Befunde werden im Lichte fruherer Untersuchungen an C. macularius und ähnlicher Studien an anderen aquatischen Organismen eingehend erörtert. Zweifellos kommt dem Einfluß der Umwelt - insbesondere während der sehr frühen Ontogenie - eine hervorragende Bedeutung zu für die funktionellen und strukturellen Eigenschaften und damit für die ökologische Potenz des aufwachsenden Individuums.
\end{abstract}

\section{INTRODUCTION}

The teleost Cyprinodon macularius BAIRD \& GIRARD 1853 can tolerate considerable ranges of temperature, salinity and oxygen (MrLLER 1948, BARLow 1958a, b, KINNE 1960, KINNE \& KINNE 1962a, b, KINNE 1963a). Irs considerable euryplasticity and the fact that $C$. macularius reproduces readily under laboratory conditions makes 
it a convenient experimental animal for the study of the modifying effects of environmental stresses on both functional and structural characteristics.

The present study is concerned with the effects of temperature and salinity on body size and shape of fry newly hatched from eggs which had been laid at $28^{\circ} \mathrm{C}$ and $35 \% \mathrm{~S}$ and transferred 4 hours after natural insemination into a variety of temperature and salinity conditions (Table 1). Previous studies by KINNE \& KINNE (1962a, b) had shown that temperature, salinity and oxygen may greatly affect the rate of

Table 1

Temperature-salinity combinations of the incubation media employed and the resulting saturation values (from normal dry atmosphere) for dissolved ambient oxygen $(\mathrm{ml} \mathrm{O} / \mathrm{l})$; the latter were taken from Figure 2 in Kinne \& Kinne (1962b)

\begin{tabular}{|cccc|}
\hline Temperature & Fresh water & $35 \%$ & $70 \%$ \\
\hline $\mathbf{2 6 ^ { \circ } \mathrm { C }}$ & 5.9 & 4.8 & 3.7 \\
$\mathbf{2 8 ^ { \circ } \mathrm { C }}$ & 5.8 & 4.7 & 3.6 \\
$31^{\circ} \mathrm{C}$ & 5.5 & 4.5 & 3.5 \\
$32^{\circ} \mathrm{C}$ & 5.5 & 4.5 & 3.4 \\
$33^{\circ} \mathrm{C}$ & 5.4 & 4.4 & 3.4 \\
$34^{\circ} \mathrm{C}$ & 5.4 & 4.4 & 3.3 \\
$35^{\circ} \mathrm{C}$ & 5.3 & 4.3 & 3.3 \\
$36^{0} \mathrm{C}$ & 5.3 & 4.3 & 3.2 \\
\hline
\end{tabular}

embryonic development in $C$. macularius and modify total length at hatching. Under conditions of air saturation and in a constant salinity of $35 \%$, hatching length decreases with increasing temperature $\left(28^{\circ}\right.$ to $\left.35^{\circ} \mathrm{C}\right)$, and, at a constant temperature of $31.8^{\circ} \mathrm{C}$, it decreases with increasing salinity (half fresh water to $70 \% 00$ ). These results led the present authors to investigate the structural consequences of exposure to different constant temperatures and salinities during embryonic development in some more detail. A preliminary note about our results has been published elsewhere (KINNE \& SWEET 1964).

\section{MATERIAL AND METHODS}

Cyprinodon macularius BAIRD \& GIRARD 1853 of the family Cyprinodontidae lives in shore pools, drainages, creeks and springs near the Salton Sea, California, U.S.A., and reaches a total length of up to some $45 \mathrm{~mm}$. In its natural habitat, salinities may range from fresh water to about 80 or even $90 \%$, and water temperatures from $8^{\circ}$ to about $40^{\circ} \mathrm{C}$; for details - also on the distributional range of the species consult KINNE (1960). In all experimental conditions referred to below, the water was aerated by washed, humidified air of a reduced $\mathrm{CO}_{2}$ content, keeping air saturation values for ambient dissolved oxygen at some $100 \pm 5 \%$.

The parent generation used represents the $\mathrm{F}_{4}$ generation of fish that were caught in the Salton Sea. The $\mathrm{F}_{2}$ was obtained from 1 male and 1 female in order to provide material with similar genetic background. All four generations were kept 
at a temperature of $28 \pm 2.0^{\circ} \mathrm{C}$, a salinity of $35 \pm 3 \%$ (air-saturated water), and a 14 hour day (a combination of day light, light from incandescent lamps and from fluorescent cool white tubes) of a light intensity of some 30 to $40 \mathrm{ft}-\mathrm{c}$ (Weston Illumination Meter, based on the New Candle) at water surface. The water in the aquaria was filtered through glass wool and charcoal; for other details on experimental conditions and food, see KINNE (1960).

Experimental conditions for spawning groups. All eggs were obtained from three spawning groups. Each group consisted of 1 female and 3 males held in a 120 liter aquarium (at $28 \pm 0.5^{\circ} \mathrm{C}$ and $35 \pm 1 \%$ ), both sexes separated by a glass partition. Spawning was initiated by transferring one of the three males into the female's section at intervals of 3 to 4 days. The 3 spawning groups were exposed to a $141 / 2$ hour day beginning and ending with a 30 minute period of low light intensity, the full light intensity lasting $13^{1 / 2}$ hours. They were fed a mixture of frozen adult brine shrimp (Artemia salina), dried fish food "Spawn" (made by the General Development Corp., and containing vitamins, hormones and potassium iodine) and occasionally white worms Enchytraeus albidus HENLE. The pH remained always within the range of 8.2 to 8.5 and thus was similar to field ranges in the Salton Sea.

Spawning and egg collection. Usually spawning began a few minutes after transfer of the male into the female's section and was allowed to last approximately 20 minutes, permitting a rather accurate determination of average time of fertilization. The naturally inseminated eggs were attached to cheese cloth (positioned on the bottom of the female's section and held in place by solid glass rods) or to nylon netting (mesh size about $1 \mathrm{~mm}$ ) stretched over a plexiglass frame. After a period of 4 hours, within which the egg membranes were sufficiently hardened, the eggs were gently collected by hand or with a wide eyedropper.

Egg development. The collected eggs were transferred into special egg holders (plastic dishes of approximately $8 \mathrm{~cm}$ diameter with a nylon net bottom of $1 \mathrm{~mm}$ mesh size) which were suspended in a shallow 2 liter jar thoroughly aerated with washed and humidified air. All jars were placed into constant temperature baths. The temperature of the air supply was also adjusted to that of the water bath resulting in a temperature constancy in the jars of $\pm 0.2^{\circ} \mathrm{C}$. Incubation temperatures ranged from $26^{\circ}$ to $36^{\circ} \mathrm{C}$; incubation salinities were: fresh water (conditioned Toronto tap water; for chemical analysis see KINNE \& KINNE 1962b, p. 233), 35\% and 70\%0 (conditioned tap water plus sea salt from Büsum, Germany; filtered); these salinities were maintained with $\pm 1 \%$ (Table 1 ).

Fixation of newly hatched fry. Hatched young were removed within a period of 60 minutes (in a few cases 100 minutes) after hatching and immediately fixed in an osmotically adjusted Zenker formol solution at $25^{\circ} \mathrm{C}$. Such procedure was necessary because of the changes in shape and size that tend to occur soon after hatching. All fixed fry were stored in $70 \%$ ethanol and measured within a few days. Specimens curled in the fixation process or showing obvious body deformations were excluded from measurement.

Measurements were performed under a binocular microscope fitted with a graduated, calibrated eyepiece. Determinations of total and standard length are accurate to $0.05 \mathrm{~mm}$, those of the other dimensions, up to $0.005 \mathrm{~mm}$. All side measurements 
were taken on the left side of the fish. The body dimensions measured are specified below (see also Fig. 1):

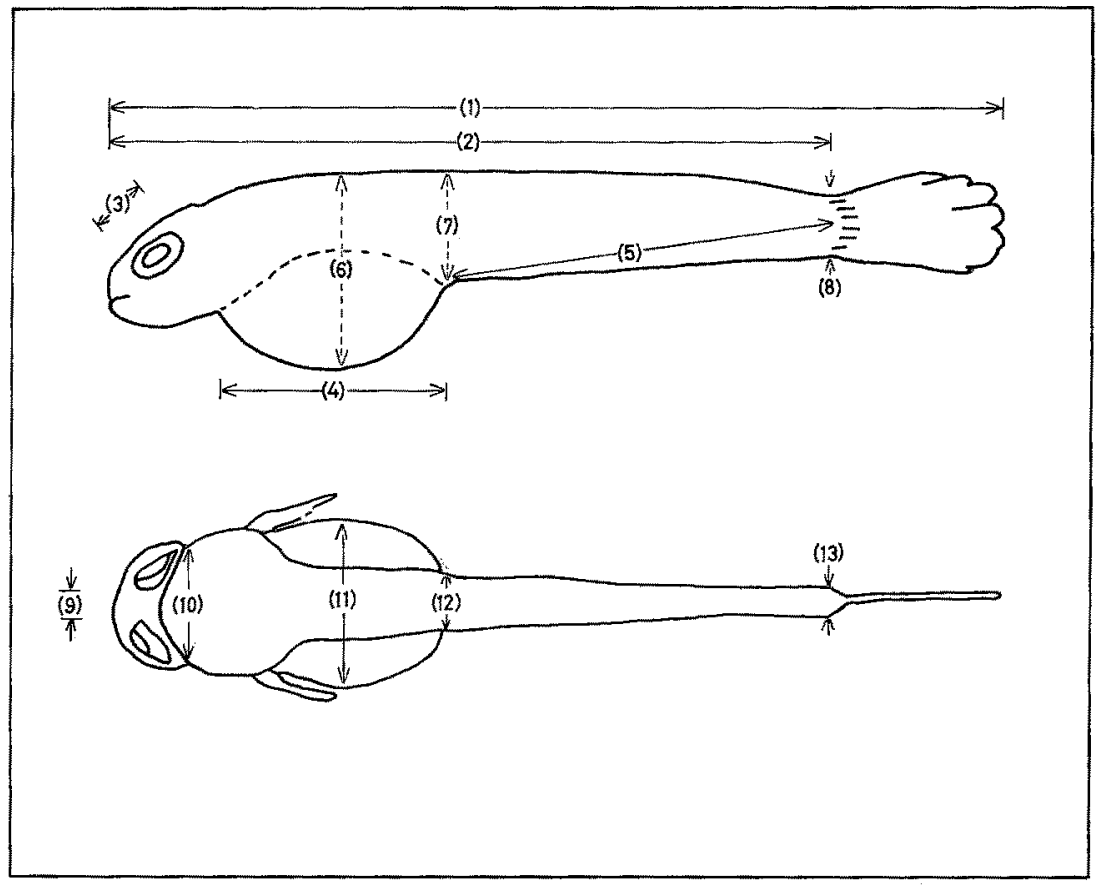

Fig. 1: Diagram of a newly hatched Cyprinodon macularius viewed from left side and from top, showing the 13 dimensions measured

(1) Total length: the straight line distance from the tip of the snout to the end of the caudal fin with the mouth in a normal closed position.

(2) Standard length: the straight line distance from the tip of the snout, in a normal closed position, to the structural base of the caudal fin.

(3) Orbit length: the greatest distance across the orbital rim. This maximum axis occurs at about $30^{\circ}$ to the horizontal.

(4) Yolksaclength: the straight line distance from the anterior beginning of the yolk sac in the head region to the posterior ending of the yolk sac in the abdominal region. (In embryos that are prematurely hatched, there is no distinct demarcation between the body and the yolk sac beginning.)

(5) Caudal peduncle length: the oblique straight line distance between the posterior ending of the yolk sac and the hidden structural base of the middle caudal fin ray.

(6) Maximum body depth: the greatest vertical body dimension, generally taken through the mid yolk sac region.

(7) Minimum body depth: the greatest vertical distance between the back and the ventral surface of the caudal peduncle, measured immediately caudal to the yolk sac. 
(8) Caudal peduncle depth: the vertical distance across the narrowest part of the caudal peduncle, just at the structural base of the caudal fin.

(9) Least interorbital width: the least distance, viewed from above, between the rims of the orbits.

(10) Head width: the greatest horizontal distance across the developing opercles, measured from above.

(11) Maximum body width: the greatest horizontal dimension across the body, viewed from above; generally taken through the mid region of the yolk sac.

(12) Minimum body width: the greatest horizontal distance, viewed from above, across the caudal peduncle, just caudal to the yolk sac.

(13) Minimum caudal width: the least horizontal distance, viewed from above, across the caudal peduncle (just anterior to its marked constriction into the caudal fin).

The 13 body dimensions measured are expressed both as absolute values in $\mathrm{mm}$ and as percentages of total body length (average absolute values divided by average total length values times 100). The absolute values are presented in Tables 3 to 10 , the percentage values in Figures 3 to 5. In each salinity, a total of about 32 individuals was measured.

\section{RESULTS}

\section{Mortality}

In all three salinity levels tested, mortality during the period between fertilization and hatching was $100 \%$ at a constant temperature of $36^{\circ} \mathrm{C}$. In fresh water average mortalities were: $19 \%$ at temperatures between $28^{\circ}$ and $33^{\circ} \mathrm{C}$, and $56 \%$ at $34^{\circ} \mathrm{C}$. In $35 \%$ average mortalities were $18 \%$ at $28^{\circ} \mathrm{C}$ and $31^{\circ} \mathrm{C}$ respectively, $61 \%$ at $34^{\circ} \mathrm{C}$ and $76 \%$ at $35^{\circ} \mathrm{C}$. In $70 \%$ no significant differences were found within the temperature range $26^{\circ}$ to $31^{\circ} \mathrm{C}$; average mortalities were $47 \%$. From these data it becomes evident that temperatures of $34^{\circ} \mathrm{C}$ and higher are critical in fresh water and $35 \%$. A more detailed account on egg mortality during incubation in C. macularius was given by KINNE \& $\operatorname{KinNE}(1962 a$, b). These two authors have furthermore reported that salinity may modify the upper critical temperatures (indicated by inflections in rate temperature curves of embryonic development) as well as the upper lethal temperatures of incubation (lowest of the constant high temperature levels at which $100 \%$ of the embryos die previous to hatching). The upper critical temperatures were found to be about $35^{\circ} \mathrm{C}$ in fresh water, $34^{\circ}$ to $35^{\circ} \mathrm{C}$ in $35 \%$ and $31.8^{\circ} \mathrm{C}$ in $70 \%$; uppex lethal temperatures were: $36.1^{\circ} \mathrm{C}$ in fresh water, $35.9^{\circ} \mathrm{C}$ in $35 \%, 34.0^{\circ} \mathrm{C}$ in $45 \% 00,33.2^{\circ} \mathrm{C}$ in $55 \%$ and $32.5^{\circ} \mathrm{C}$ in $70 \%$.

\section{Length measurements}

Total length (1) and standard length (2) of the body of newly hatched fry are affected by temperature and salinity conditions during incubation in a rather complex way (Table 2, Fig. 2). Since the structural base of the caudal fin was 
frequently difficult to make out exactly, total length is considered the more exact measurement in the present case, and all relative data have therefore been expressed as percentages of total length rather than of standard length.

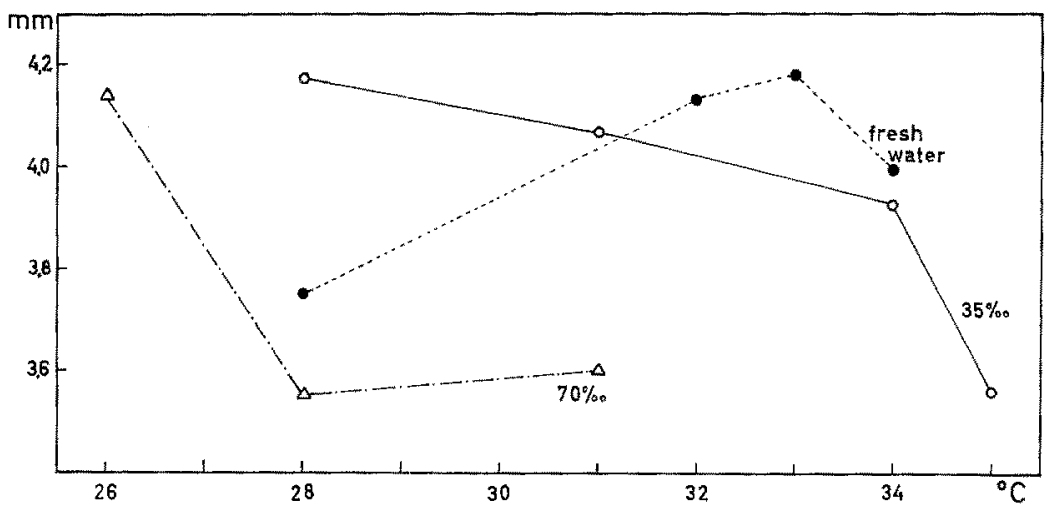

Fig. 2: Total length of newly hatched C. macularius as a function of temperature and salinity

Table 2

Total length and standard length (in $\mathrm{mm}$ ) of Cyprinodon macularius, newly hatched from eggs that were incubated at different constant temperatures and salinities. $\bar{X}:$ means; $\mathrm{S}_{\bar{x}}$ : standard errors of the means

\begin{tabular}{|c|c|c|c|c|c|c|c|c|c|}
\hline \multirow{3}{*}{$\begin{array}{l}\text { Temper- } \\
\text { ature }\end{array}$} & \multirow{2}{*}{\multicolumn{2}{|c|}{$\begin{array}{cc}\text { Fresh } & \text { water } \\
\text { total } & \text { standard } \\
\text { length } & \text { length }\end{array}$}} & \multicolumn{4}{|c|}{$35 \%$} & \multicolumn{3}{|c|}{$70 \%$} \\
\hline & & & \multicolumn{2}{|c|}{$\begin{array}{c}\text { total } \\
\text { length }\end{array}$} & \multicolumn{2}{|c|}{$\begin{array}{l}\text { standard } \\
\text { length }\end{array}$} & $\begin{array}{c}\text { total } \\
\text { length }\end{array}$ & \multicolumn{2}{|c|}{$\begin{array}{l}\text { standard } \\
\text { length }\end{array}$} \\
\hline & $\mathrm{S}_{\bar{x}}$ & $\begin{array}{ll}\bar{X} & \mathrm{~S}_{\bar{x}}\end{array}$ & $\bar{X}$ & $S_{\bar{x}}$ & $\bar{X}$ & $\mathrm{~S}_{\bar{x}}$ & $\mathrm{~S}_{\vec{x}}$ & $\ddot{X}$ & $\mathrm{~S}_{\bar{x}}$ \\
\hline $26^{\circ} \mathrm{C}$ & - & - & & - & & - & $4.14 \pm .12$ & 3.23 & \pm .07 \\
\hline $28^{\circ} \mathrm{C}$ & $3.75 \pm .12$ & $3.10 \pm .04$ & & \pm .05 & 3.3 & \pm .05 & $3.55 \pm .07$ & 2.84 & \pm .04 \\
\hline $31^{\circ} \mathrm{C}$ & - & 二 & & \pm .01 & & \pm .04 & $3.60 \pm .03$ & 2.89 & \pm .01 \\
\hline $32^{\circ} \mathrm{C}$ & $4.13 \pm .04$ & $3.32 \pm .08$ & & - & & - & - & & $=$ \\
\hline $33^{\circ} \mathrm{C}$ & $4.18 \pm .10$ & $3.45 \pm .13$ & & - & & - & - & & - \\
\hline $34^{\circ} \mathrm{C}$ & $3.99 \pm .08$ & $3.14 \pm .05$ & 3.9 & \pm .10 & & \pm .04 & - & & - \\
\hline $35^{\circ} \mathrm{C}$ & - & - & 3.5 & \pm .15 & 2.9 & \pm .17 & - & & - \\
\hline
\end{tabular}

In fresh water, total length increases from $28^{\circ} \mathrm{C}$ to $33^{\circ} \mathrm{C}$ and at still higher temperatures $\left(34^{\circ} \mathrm{C}\right.$ ) declines (Fig. 2). In $35 \%$ total length reaches the highest values in the lowest temperature level employed $\left(28^{\circ} \mathrm{C}\right)$ and decreases progressively with decreasing temperature, especially above $34^{\circ} \mathrm{C}$. The fresh water and the $35 \%$ curves are essentially similar in shape but have different slopes. Both curves intersect near $31^{\circ} \mathrm{C}$. Below $31^{\circ} \mathrm{C}$ the newly hatched individuals are larger in $35 \%$; above $31^{\circ} \mathrm{C}$ they are larger in fresh water. In $70 \%$ total length is significantly smaller than in the other two salt concentrations, and the curve has a different shape; similarly to $35 \%$, the highest values are found in the lowest temperature level $\left(26^{\circ} \mathrm{C}\right)$; at $28^{\circ} \mathrm{C}$, however, total length is considerably reduced, and at still higher test temperatures, it seems to level off or to increase slightly again. 


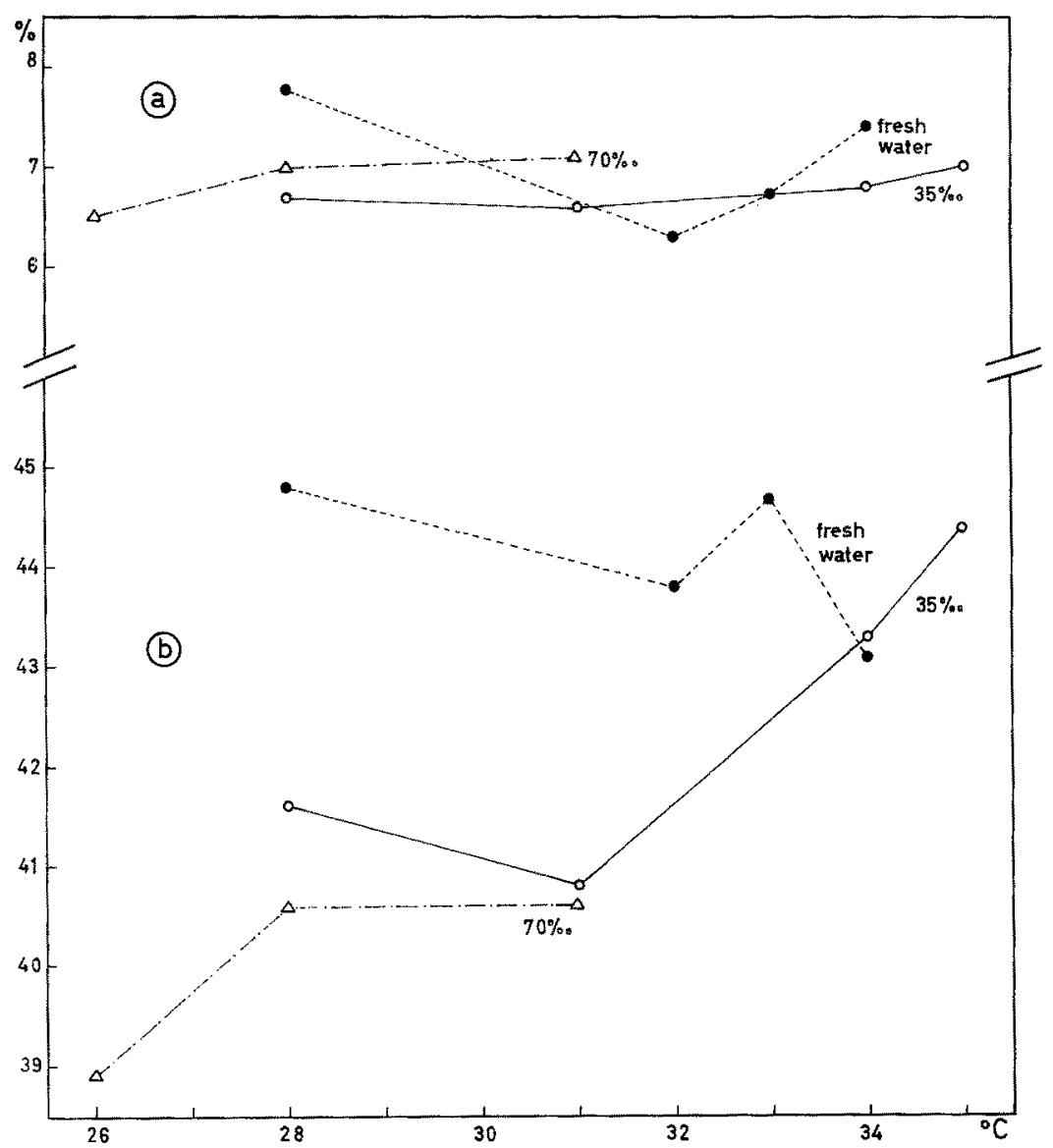

Fig. 3: Orbit length (a) and caudal peduncle length (b) of newly hatched $C$. macularius expressed as percentages of their total length. Average values based on 6 to 8 individuals in each case

Orbit length (3), yolk sac length (4), caudal peduncle length (5). Orbit length measurements are presented in Table 3 (absolute values) and in Figure $3 a$ (relative values, expressed as percentages of total length). If plotted, the absolute data result in $v$-shaped curves in fresh water and in $70 \%$, and in a similar curve, as has been obtained for total length, in $35 \%$; in all temperature levels tested, orbit length is smallest in $70 \%$. A plot of the percentage values against temperature (Fig. $3 a$ ) results in a v-shaped curve in fresh water; the greatest total length values at $32^{\circ}$ and $33^{\circ} \mathrm{C}$ (Fig. 2) are correlated with minimum orbit length values; relative orbit length increases both below and above $32^{\circ} \mathrm{C}$ (Fig. 3a). In $35 \%$ and in $70 \%$, percentages of orbit length result in more or less straight lines with a slightly positive angle, suggesting that with increasing temperature, orbit length increases rather proportionally to total length; the relative longest orbits are attained at the highest temperature levels. 
Table 3

Orbit length (in $\mathrm{mm}$ ) of C. macularius newly hatched from eggs that were incubated at different constant temperatures and salinities. $X$ : means; $\mathrm{S}_{\bar{x}}$ : standard errors

\begin{tabular}{|c|c|c|c|}
\hline Temperature & $\begin{array}{c}\text { Fresh water } \\
\underset{X}{S_{\bar{x}}}\end{array}$ & $\bar{X}^{35 \%} \mathrm{~S}_{\vec{x}}$ & $\bar{X}^{70 \%} \mathrm{~S}_{\bar{x}}$ \\
\hline $26^{\circ} \mathrm{C}$ & - & - & $.268 \pm .014$ \\
\hline $28^{\circ} \mathrm{C}$ & $.292 \pm .004$ & $.282 \pm .006$ & $.249 \pm .001$ \\
\hline $31^{0} \mathrm{C}$ & - & $.270 \pm .008$ & $.257 \pm .003$ \\
\hline $32^{16} \mathrm{C}$ & $.260 \pm .007$ & - & $=$ \\
\hline $33^{\circ} \mathrm{C}$ & $.280 \pm .012$ & - & - \\
\hline $34^{\circ} \mathrm{C}$ & $.297 \pm .005$ & $.266 \pm .003$ & - \\
\hline $35^{\circ} \mathrm{C}$ & $=$ & $.249 \pm .011$ & - \\
\hline
\end{tabular}

Yolk sac length and caudal peduncle length measurements showed considerable variations. In the case of the yolk sac length, variations were due to (a) actual differences in size and shape of the yolk sac at hatching, (b) rapid changes in yolk sac dimensions subsequent to hatching. Yolk sac measurements will not be considered here in any detail. With respect to caudal peduncle length, the information obtained must be interpreted with reservation. If plotted, the absolute values show basically the same trends, as does total length. If expressed as percentages of total length, it becomes apparent that caudal peduncle length takes up the highest proportion of total length in fresh water, a smaller proportion in $35 \%$ (except for the highest temperature levels $34^{\circ}$ and $35^{\circ} \mathrm{C}$ ) and the smallest proportion. in $70 \%$ (Fig. 3b). Thus, in general, there appears to be a reduction in relative peduncle length with increasing salinity. Such a trend has also been found by KINNE (unpublished) in 20 to $30 \mathrm{~mm}$ long C. macularius reared in fresh water and $35 \%$ respectively at $25^{\circ} \mathrm{C}$. In regard to temperature, relative caudal peduncle length tends to decrease with increasing temperature in fresh water but tends to increase under the same conditions in 35 and $70 \%$. In the total length versus temperature plot (Fig. 2) then, increase in total length in fresh water up to $33^{\circ} \mathrm{C}$, as well as the decrease in $35 \%$ and $70 \%$, appears to be due to proportional length changes of the anterior body (and possibly the caudal fin rather than of the caudal peduncle).

\section{Depth measurements}

Maximum body depth (6) is subject to increased variability due to changes in the size and shape of the yolk sac. Since the dimensions of the yolk sac may undergo rapid changes immediately after hatching, they are highly dependent upon the length of the period between hatching and fixation. Absolute values and percentages give basically similarly shaped curves. Absolute values are presented in Table 4, percentages in Figure $4 a$. In fresh water a v-or u-shaped curve is obtained with a minimum at $32^{\circ} \mathrm{C}$; in $35 \%$ the average values zigzag without showing a definite trend (Fig. 4a); in $70 \%$ the curve has a somewhat similar pattern as does the total length curve (Fig. 2).

Minimum body depth (7) measurements are presented in Table 5 (absolute values) and in Figure $4 \mathrm{~b}$ (percentages); in both cases, similarly shaped curves are 


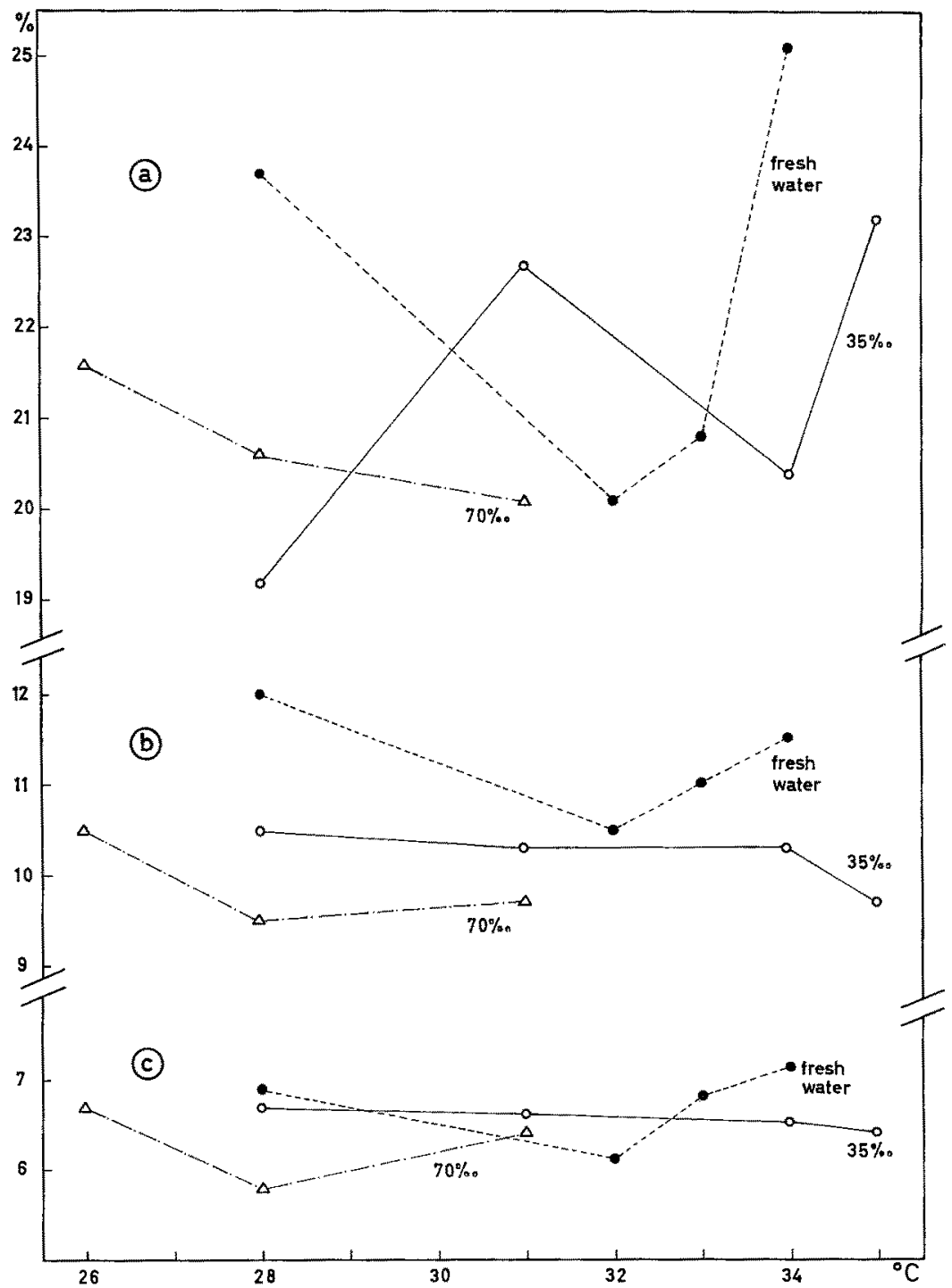

Fig. 4: Maximum body depth (a), minimum body depth $(b)$ and caudal peduncle depth (c) of newly hatched C. macularius expressed as percentages of total length. Average values based on 6 to 8 individuals in each case

obtained. The percentage values result in $\mathrm{v}$-shaped curves both in fresh water and in $70 \%$. The $35 \%$ plot gives a rather straight line between $28^{\circ}$ and $34^{\circ} \mathrm{C}$, which then decreases toward $35^{\circ} \mathrm{C}$ (critical temperature), indicating that minimum body depth varies almost directly in proportion to total length. Minimum body depth (absolute values and percentages) decreases at all temperatures with increasing salinity (fresh water $>35 \%>70 \%$. 
Caudal peduncle depth (8) measurements are given in Table 6 (absolute values) and in Figure $4 c$ (percentages); in both cases a plot results in curves of basically similar shape. The percentage values yield curves comparable to those of minimum body depth: open $\mathrm{v}$-shaped curves in fresh water and $70 \%$, and an almost horizontal line in $35 \%$.

\section{Table 4}

Maximum body depth (in $\mathrm{mm}$ ) of newly hatched C. macularius

\begin{tabular}{|c|c|c|c|}
\hline Temperature & Fresh water & $35 \%$ & $70 \%$ \\
\hline & $\bar{X} \quad \mathrm{~S}_{\bar{x}}$ & $\begin{array}{ll}X & S_{\bar{x}}\end{array}$ & \\
\hline $26^{\prime \prime} \mathrm{C}$ & - & - & $.876 \pm .010$ \\
\hline $28^{\circ} \mathrm{C}$ & $.889 \pm .037$ & $.803 \pm .011$ & $.731 \pm .003$ \\
\hline $31^{\circ} \mathrm{C}$ & - & $.923 \pm .029$ & $.725 \pm .013$ \\
\hline $32^{0} \mathrm{C}$ & $.829 \pm .046$ & - & 二 \\
\hline $33^{\circ} \mathrm{C}$ & $.870 \pm .018$ & - & - \\
\hline $34^{\circ} \mathrm{C}$ & $1.000 \pm .033$ & $.800 \pm .030$ & - \\
\hline $35^{\circ} \mathrm{C}$ & - & $.827 \pm .022$ & - \\
\hline
\end{tabular}

Table 5

Minimum body depth (in $\mathrm{mm}$ ) of newly hatched C. macularius

\begin{tabular}{|c|c|c|c|}
\hline Temperature & $\begin{array}{l}\text { Fresh water } \\
\underset{X}{ } \mathrm{~S}_{\bar{x}}\end{array}$ & $\bar{X} \stackrel{35 \%}{S_{\bar{x}}}$ & $\bar{X} \stackrel{70 \%}{S_{\bar{x}}}$ \\
\hline $26^{\circ} \mathrm{C}$ & - & - & $.435 \pm .011$ \\
\hline $28^{\circ} \mathrm{C}$ & $.450 \pm .022$ & $.440 \pm .006$ & $.337 \pm .006$ \\
\hline $31^{\prime} \mathrm{C}$ & - & $.420 \pm .015$ & $.350 \pm .007$ \\
\hline $32^{0} \mathrm{C}$ & $.433 \pm .005$ & - & - \\
\hline $33^{\circ} \mathrm{C}$ & $.460 \pm .018$ & - & - \\
\hline $34^{\circ} \mathrm{C}$ & $.457 \pm .014$ & $.405 \pm .013$ & - \\
\hline $35^{\circ} \mathrm{C}$ & - & $.345 \pm .009$ & - \\
\hline
\end{tabular}

Table 6

Caudal peduncle depth (in $\mathrm{mm}$ ) of newly hatched C. macularius

\begin{tabular}{|c|c|c|c|}
\hline Temperature & $\begin{array}{c}\text { Fresh water } \\
\bar{X} \mathrm{~S}_{\bar{X}}\end{array}$ & $\bar{X} \stackrel{35 \%}{\mathrm{~S}_{\bar{r}}}$ & $\bar{x}^{70 \%}$ \\
\hline $26^{\prime \prime} \mathrm{C}$ & - & - & $276+005$ \\
\hline $28^{\circ} \mathrm{C}$ & $.259 \pm .012$ & $.279 \pm .008$ & $.205 \pm .006$ \\
\hline $31^{\circ} \mathrm{C}$ & - & $.267 \pm .006$ & $.232 \pm .007$ \\
\hline $32^{0} \mathrm{C}$ & $.251 \pm .066$ & - & - \\
\hline $33^{0} \mathrm{C}$ & $.286 \pm .019$ & - & - \\
\hline $34^{\circ} \mathrm{C}$ & $.284 \pm .006$ & $.257 \pm .003$ & - \\
\hline $35^{\circ} \mathrm{C}$ & - & $.227 \pm .011$ & - \\
\hline
\end{tabular}

General considerations on depth measurements (Fig. 4a, b, c) show that the plots for fresh water and $70 \%$ represent open $v$-type curves with the lowest relative depth values at intermediate temperatures and the greatest relative depths both at the lowest and highest temperatures tested (exception: maximum body depth in 70\%). By 
contrast, the $35 \%$ data result in a more or less horizontal line with a slightly decreasing slope towards higher temperatures indicating considerable proportionality with total length (exception: maximum body depth). The exceptions in the case of the maximum body depth data do not carry too much weight since this measurement varies considerably - as has already been pointed out - with the size and shape of the yolk sac. In general, depth dimensions tend to decrease in the higher salt concentrations.

\section{Width measurements}

Least interorbital width (9) is a rather difficult measurement to take accurately; the values obtained showed much scatter. Absolute values are given in Table 7 , percentages in Figure $5 \mathrm{a}$. The percentage values result in a $\mathrm{v}$-shaped curve in fresh water, a somewhat irregular zigzag curve in $35 \%$ and a straight line with a negative slope in $70 \%$. Both in $35 \%$ and in $70 \%$ the least interorbital width appears to decrease with increasing temperature.

Table 7

Least inter-orbit width (in $\mathrm{mm}$ ) of newly hatched C. macularius

\begin{tabular}{|c|c|c|c|}
\hline Temperature & Fresh water & $X^{35 \%}$ & $70 \%$ \\
\hline $26^{0} \mathrm{C}$ & - & - & $205+003$ \\
\hline $28^{\circ} \mathrm{C}$ & $.233 \pm .006$ & $.207 \pm .003$ & $.170 \pm .005$ \\
\hline $31^{\circ} \mathrm{C}$ & 二 & $.210 \pm .002$ & $.154 \pm .004$ \\
\hline $32^{\circ} \mathrm{C}$ & $.152 \pm .008$ & $=$ & 二 \\
\hline $33^{\circ} \mathrm{C}$ & $.195 \pm .009$ & - & - \\
\hline $34^{\circ} \mathrm{C}$ & $.217 \pm .008$ & $.135 \pm .002$ & - \\
\hline $35^{\circ} \mathrm{C}$ & - & $.146 \pm .004$ & - \\
\hline
\end{tabular}

Table 8

Head width (in $\mathrm{mm}$ ) of newly hatched C. macularius

\begin{tabular}{|c|c|c|c|}
\hline Temperature & $\begin{array}{l}\text { Fresh water } \\
\underset{X}{ } \mathrm{~S}_{\bar{x}}\end{array}$ & $x^{35} \stackrel{\mathrm{S}_{\bar{x}}}{\mathrm{~S}_{\bar{x}}}$ & $X^{70 \%} \stackrel{700}{S_{\tilde{x}}}$ \\
\hline $26^{\circ} \mathrm{C}$ & - & - & $.730 \pm .017$ \\
\hline $28^{\circ} \mathrm{C}$ & $.745 \pm .026$ & $.755 \pm .006$ & $.600 \pm .007$ \\
\hline $31^{\circ} \mathrm{C}$ & - & $.710 \pm .014$ & $.655 \pm .007$ \\
\hline $32^{9} \mathrm{C}$ & $.700 \pm .029$ & - & - \\
\hline $3^{3}{ }^{\theta} \mathrm{C}$ & $.730 \pm .042$ & - & - \\
\hline $34^{\circ} \mathrm{C}$ & $.790 \pm .023$ & $.610 \pm .013$ & - \\
\hline $35^{0} \mathrm{C}$ & - & $.550 \pm .005$ & - \\
\hline
\end{tabular}

Head width (10) measurements are presented in Table 8 (absolute values) and in Figure $5 b$ (percentages); in both cases basically similarly shaped curves are obtained. The percentage values result in $\mathrm{v}$-shaped curves in both freshwater and $70 \%$. In $35 \%$ head width decreases significantly with increasing temperature. 


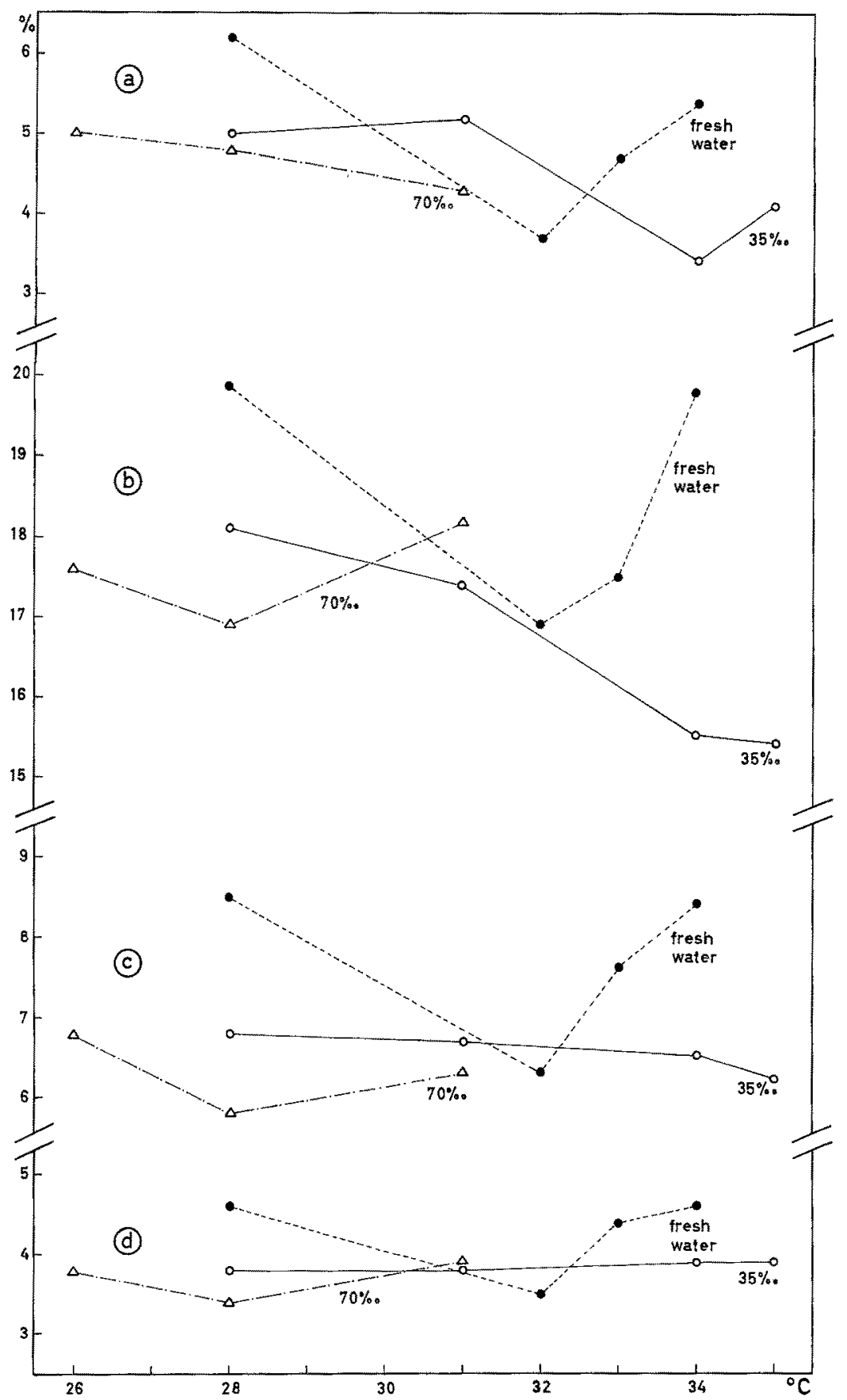

Fig. 5: Least interorbital width $(a)$, head width $(b)$, minimum body width $(c)$ and minimum caudal width $(d)$ of newly hatched $C$. macularius expressed as percentages of total length. Average values based on 6 to 8 individuals in each case 
Maximumbody width (11) is measured across the yolk sac and hence results in widely scattered values. In all three salinities, relative maximum body width appears to increase somewhat with increasing temperature. There is some indication that yolk sac width tends to increase under warmer incubation conditions.

Minimum body width (12) measurements are given in Table 9 (absolute values) and in Figure $5 \mathrm{c}$ (percentages); in both cases quite similar curves are obtained. The relative plots result in v-shaped curves both in fresh water and $70 \%$, but in a straight line with a slightly negative slope toward higher temperatures in $35 \%$. In $70 \%$ relative minimum body width is considerably smaller than in fresh water or in $35 \%$.

Table 9

Minimum body width (in mm) of newly hatched C. macularius

\begin{tabular}{|c|c|c|c|}
\hline Temperature & Fresh water & $35 \%$ & $70 \%$ \\
\hline & $\begin{array}{ll}X & \mathrm{~S}_{\bar{x}}\end{array}$ & $\begin{array}{ll}\bar{X} & \mathrm{~S}_{\bar{x}}\end{array}$ & $\bar{X} \quad \mathrm{~S}_{\bar{x}}$ \\
\hline $26^{\circ} \mathrm{C}$ & - & - & $.282 \pm .012$ \\
\hline $28^{\circ} \mathrm{C}$ & $.320 \pm .018$ & $.285 \pm .006$ & $.205 \pm .003$ \\
\hline $31^{\circ} \mathrm{C}$ & - & $.272 \pm .011$ & $.225 \pm .002$ \\
\hline $32^{\circ} \mathrm{C}$ & $.262 \pm .015$ & - & $=$ \\
\hline $33^{\circ} \mathrm{C}$ & $.317 \pm .016$ & - & - \\
\hline $34^{\circ} \mathrm{C}$ & $.337 \pm .007$ & $.257 \pm .006$ & - \\
\hline $35^{\circ} \mathrm{C}$ & 二 & $.220 \pm .008$ & - \\
\hline
\end{tabular}

Table 10

Minimum caudal width (in $\mathrm{mm}$ ) of newly hatched C. macularius

\begin{tabular}{|c|c|c|c|}
\hline Temperature & Fresh water & $\bar{X} 35 \%$ & $70 \%$ \\
\hline & & & \\
\hline $26^{\circ} \mathrm{C}$ & - & - & $.158 \pm .006$ \\
\hline $28^{\circ} \mathrm{C}$ & $.174 \pm .005$ & $.158 \pm .004$ & $.121 \pm .003$ \\
\hline $31^{\circ} \mathrm{C}$ & $=$ & $.153 \pm .006$ & $.141 \pm .003$ \\
\hline $32^{\circ} \mathrm{C}$ & $.143 \pm .008$ & = & 二 \\
\hline $33^{\circ} \mathrm{C}$ & $.183 \pm .006$ & - & - \\
\hline $34^{\circ} \mathrm{C}$ & $.183 \pm .004$ & $.153 \pm .010$ & - \\
\hline $35^{\circ} \mathrm{C}$ & $=$ & $.140 \pm .004$ & - \\
\hline
\end{tabular}

Minimumcaudal width (13) measurements are shown in Table 10 (absolute values) and in Figure $5 \mathrm{~d}$ (percentages); in both cases the resulting curves are similar. The percentage values result again in $v$-shaped curves in fresh water and $70 \%$, but in a rather straight line in $35 \%$.

General considerations on width measurements (Fig. $5 \mathrm{a}, \mathrm{b}, \mathrm{c}, \mathrm{d}$ ) demonstrate that the plots for fresh water and $70 \%$ represent $\mathrm{v}$-shaped curves with the lowest relative width values at intermediate temperatures and the greatest relative widths both at the lowest and highest temperatures tested (exception: least interorbital width in $70 \%$ ). In $35 \%$ more or less straight lines are obtained with decreasing slopes in the case of the first three width measurements and a rather horizontal line in the case of the minimum caudal width. There seems to be a tendency for the various width dimensions 
to decrease in higher salinities. These general trends are all quite similar to those obtained with respect to the depth dimensions.

\section{DISCUSSION}

\section{Information concerning Cyprinodon macularius}

The present study has shown that temperature and salinity conditions effective during incubation may significantly modify a variety of structural characters in newly hatched individuals of $C y$ prinodon macularius of similar genetic background. Although egg mortalities may be rather high under extreme conditions of temperature and salinity (p. 53), our observations indicate that at least a major amount of these structural modifications was caused by direct environmental influences on the developing embryos greater length at fixation.

In $35 \%$ total length and stardard length at hatching decrease with increasing temperature. In $70 \%$ both dimensions decrease considerably from $26^{\circ}$ to $28^{\circ} \mathrm{C}$, but there seems to be little change at $31^{\circ} \mathrm{C}$, possibly a slight increase. A reduction of body length with increasing temperature has been reported for numerous organisms and appears to be a rather general phenomenon. In fresh water, however, body length of newly hatched fry increases from $28^{\circ}$ to $33^{\circ} \mathrm{C}$ and only at still higher, more or less critical temperatures begins to decline. As a consequence of such differences, the curves obtained for $35 \%$ and fresh water intersect: at a temperature of $31^{\circ} \mathrm{C}$ and below, newly hatched fish are larger in $35 \%$; at higher temperatures they are larger in fresh water. As has been demonstrated in an earlier study (KINNE 1960), grow th rates of subadult $C$. macularius at ages of 6,12 and 24 weeks respectively, show an opposite relationship: at lower temperatures $\left(15^{\circ}, 20^{\circ} \mathrm{C}\right)$ the fish grow faster in fresh water; at higher temperatures $\left(25^{\circ}, 30^{\circ}, 35^{\circ} \mathrm{C}\right)$ they grow faster in $35 \%$.

Reduction in total length of newly hatched C. macularius with increasing incubation temperature in $35 \%$ has also been reported by KinNe \& KINNE (1962b). A comparison between our data and theirs reveals quite similar data at the higher temperature levels (Table 11). The differences, especially at $28^{\circ}$ and $30^{\circ} \mathrm{C}$, are most likely due to the longer intervals between hatching and fixation employed by KrnNE \& KINNE ( 12 hours below $30^{\circ} \mathrm{C}, 1$ to 3 hours above $30^{\circ} \mathrm{C}$ versus about 60 minutes or less in the case of the present study), leading to a greater average age and consequently greater length at fixation.

Table 11

Average total length $(\mathrm{mm})$ of newly hatched C. macularius in $35 \% 0$ at different constant temperatures - a comparison

\begin{tabular}{|lccccc|}
\hline Authors & $28^{\circ} \mathrm{C}$ & $30^{\circ} \mathrm{C}$ & $32^{\circ} \mathrm{C}$ & $34^{0} \mathrm{C}$ & $35^{\circ} \mathrm{C}$ \\
\hline KINNE \& KinNe (1962b) & 5.3 & 5.0 & 4.3 & 3.9 & 3.7 \\
SWEET \& KinNe (this paper) & 4.2 & 4.1 & 4.0 & 3.9 & 3.6 \\
\hline
\end{tabular}


With the exception of the lowest temperature level in fresh water, body length tends to decrease with increasing salinity. This trend is demonstrated by Figure 2 as well as by earlier results (Table 12). A reduction of hatching length with increasing temperature as well as with increasing salinity could not have been caused by parallel changes in rates of embryonic development per se, since increasing temperatures cause acceleration, but increasing salinities cause retardation of developmental rates. It does seem possible, however, that body length at hatching may have been affected to some

Table 12

Average total hatching length of C. macularius at $31.8^{\circ} \mathrm{C}$ as a function of salinity. Averages from 8 individuals in each case. (After KINNE \& KINNE 1962b)

\begin{tabular}{|lcccc|}
\hline $\begin{array}{l}\text { Half fresh water } \\
\text { (fresh water plus } \\
\text { aqua dist., 1:1) }\end{array}$ & Fresh water & $35 \% 0$ & $55 \% 0$ & $70 \% 0$ \\
\hline $4.5 \mathrm{~mm}$ & $4.4 \mathrm{~mm}$ & $4.2 \mathrm{~mm}$ & $3.9 \mathrm{~mm}$ & $3.7 \mathrm{~mm}$ \\
\hline
\end{tabular}

extent by the amount of oxygen available to the embryo during incubation. In airsaturated water the amount of dissolved oxygen decreases with increasing temperature and increasing salinity, and retardation of developmental rates in higher salinities has been shown to be primarily due to such concomittant changes in oxygen content (KINNE \& KINNE 1962a, b). The amounts of dissolved gases, especially oxygen and carbon dioxide present in the various temperature-salinity combinations employed, may well have been of importance also with respect to other changes in body dimensions reported in this paper.

The various body depth and width proportions of newly hatched C. macularius, if plotted against temperature, result in different curves for each of the three test salinities (Figs. 4 and 5). In fresh water, and to a lesser degree in $70 \%$, v-shaped curves are obtained, demonstrating that the body reaches its minimum depth and width at intermediate temperatures $\left(32^{\circ} \mathrm{C}\right.$ in fresh water; $28^{\circ} \mathrm{C}$ in $70 \%$, and that it gets deeper and wider both in colder and warmer water. By contrast, in $35 \%$ body depths and widths change more linearly with total length indicating a considerable degree of structural harmony (isometry) throughout the tested temperature range. It appears possible that the increasing degree of disharmony in the order $35 \%<$ $70 \%<$ fresh water is related to the fact that (a) all eggs examined were laid and fertilized in $35 \%$ and remained in this salinity for 4 hours before being transferred into the test salinities, and (b) that a salinity of $35 \%$ affords near optimum conditions for growth and reproduction. KINNE (1962) has shown that growth rates and food conversion efficiencies of subadult $C$. macularius reach maximum values in individuals hatched and maintained in the spawning salinity but are reduced in fry hatched from eggs that had been transferred 3 to 6 hours after fertilization into a different salinity level. It seems possible therefore that the modifications in body form reported here would have been somewhat different in fry hatched from eggs laid (and maintained for 4 hours) in fresh water or $70 \%$ instead of in $35 \%$. No doubt, environmental influences effective during very early ontogeny may have paramount consequences for the future structural and functional properties of the individual. 
Body depth and width tend to gain with decreasing salinity, resulting in an overall reduction of the surface to volume ratio. Such a relationship has also been demonstrated for 20 to $30 \mathrm{~mm}$ long C. macularius reared at $25^{\circ} \mathrm{C}$ in fresh water and $35 \%$ respectively (KINNE unpubl.). In the hydroid Cordylophora caspia comparable responses were obtained in genetically identical material (KINNE 1956, 1958a, b): in fresh water and very low salinities, the hydranths become considerably more globular and smaller than in $15 \%$. Similar effects of low salinities have been observed under field conditions as early as 1881 when HEINCKE published his famous paper on the varieties of the herring Clupea harengus. HerNCKE writes on page 25: „Fast ausnahmslose Regel ist es, daß wenn von zwei Varietäten einer Art oder von zwei Arten einer Gattung die eine das Salzwasser, die andere das brackische oder süße Wasser bewohnt, letztere nicht nur kleiner, sondern im Körperbau gedrungener und höher ist als die größere und schlanker gebaute Form der See." Such changes in body form are likely to affect the ratio of exchange between body and environment, and - at least in faster moving organisms - the dynamics of locomotion (KINNE \& SWEET 1964).

\section{Information concerning other species}

Environmental effects on body size and form as well as on meristic characters of aquatic organisms have been reported in a number of cases. The first report known to the present authors was written by A. GunTHer (1862; quoted by G. GUNTER 1957) and concerned with the effects of temperature. Other papers dealing with temperature effects are: Möbius \& HeIncke (1883), Jordan (1891), Schmid (1917, 1919a, b, 1920, 1921, 1930), Hubbs $(1922,1926,1934)$, Schultz (1926), Rounsefell \& Dahtgren (1932), Mottley (1934, 1937), Hass (1936, 1937), Gabriel (1944), Tåning (1946, 1950), Dannevig (1950), Hempel (1953), Lindsey (1954, 1962), Seymour (1956, 1959), Blaxter (1957), Harder (1957), Morris \& Scheer (1957), Itazawa (1959), Blaxter \& Hempel (1961), Hempel \& Blaxter (1961). A number of pertinent papers has been reviewed by VLADYKov (1934), MARTIN (1949), TÅning (1944, 1952), Gunter (1957) and Kinne (1963b). Much less is known about the effects of salinity (see the recent review by KINNE 1964). Examples of reduced body size in subnormal salinities, which may be referred to as "brackish water pauperization" can be found in Remane (1934, 1940), Boettrger (1950), Pearse \& Gunter (1957), Segerstråle (1957), Moore (1958), Remane \& Schlieper (1958). In the hering Clupea barengus hatching length (at temperatures between $11.2^{\circ}$ and $11.7^{\circ} \mathrm{C}$ ) was found by HolLIDAY \& BLAXTER 1960) to increase in salinities below that of sea water $(22.7 \%,<11.5 \% 0,<5.9 \%$, while BlaXter \& Hempel (1961) reported maximum hatching lengths (at $10^{\circ} \mathrm{C}$ ) in $15^{\%} \%$, decreasing both toward the lowest $(5 \%)$ and highest $(50 \%)$ test salinities.

Most of the references available refer to field observations. In these cases it is often not possible to attribute a given structural variation to the intensity differences of a distinct environmental entity, nor is it possible to distinguish sufficiently between non-genetic and genetic (selective) components of the structural changes reported. There is urgent need for carefully conducted long-term experimental studies under controlled conditions of various combinations of environmental factors in- 
cluding conditions with fluctuating factor intensities. In spite of the impressive amount of information available at this time, we do not yet possess a sufficient body of knowledge to allow for generalizations.

Two papers published by LINDSEY $(1954,1962)$ are especially pertinent to the present study. In 1954 LINDSEY reported on temperature-controlled meristic variation. in the paradise fish Macropodus opercularis. He reared eggs from one parental pair at different constant temperatures and recorded the effects on dorsal and anal fin ray, spine and basal counts, caudal and pectoral ray counts and vertebral counts. Intermediate temperatures produced significantly fewer vertebrae than either low or high temperatures, and different rearing temperatures were shown to cause different numbers of rays, spines and basals. Although environmental effects were most pronounced when administered before hatching, some meristic series were still subject to environmental influence 20 days later. If plotted against temperature, most data result in v-shaped curves. In 1962 LINDSEY reared 21 pairs of the stickleback Gasterosteus aculeatus under various temperature and salinity conditions and examined various meristic characters. Curves of vertebrae count against rearing temperature in fresh water were $v$-shaped with the position of the minimum differing markedly between different genotypes. Similar v-shaped curves in three or more temperatures have also been obtained in other species, e. g. in Salmo trutta trutta (TÅNING 1952, MarcKManN 1954), Pleuronectes platessa (Molander \& Molander-SWedmark 1957), Channa argus (ITAzAW 1959), Oncorbynchus tshawytscha (SeYmour 1959), Oryzias latipes (ALr, pers. communication, in LINDSEY 1962). V-shaped curves can of course only be obtained in cases where a sufficient environmental gradient is offered. Despite the close morphological proximity of many of the meristic characters examined, a high degree of autonomy in their variation, both non-genetic and genetic, and little evidence of genetic linkage between meristic series were found. LINDSEY assumes that the $\mathrm{v}$-shaped curves may result from interaction of two opposing processes, one dominant at low temperatures, the other at high temperatures.

In sea trout Salmo trutta trutta (SCHMDT 1. c., Taning 1952), the lowest average number is obtained at $6^{\circ} \mathrm{C}$, while both lower and higher constant temperatures lead to higher average numbers. An increase in vertebrae number may also be caused by decreasing oxygen pressure, a decrease, by rising carbon dioxide pressure (TÅNING 1952). Experiments on the effect of salinity on vertebrae numbers in Salmo trutta trutta have so far yielded rather inconclusive results. However, HEMPEL \& Blaxter (1961) found a positive correlation between salinity and myotome number in larvae of Clupea barengus. (In 1957 BLAXTER had produced results indicating a fixed relationship between myotome counts and vertebral counts.) TÅNING (1952) comes to the conclusion that all non-genetic variations in meristic characters in sea trout follow a certain regularity, "undoubtedly determined by the metabolism within certain limits restricted genetically" (p. 192).

In his analysis on environmental control of the body form in fishes, Martin (1949) discusses relative growth ( $\log$ body part plotted against $\log$ body length) of body parts during ontogeny in 20 species. He found that the relative growth of a body part such as the head, is characterized by a series of relative growth stanzas differing in slope and in size range, over which each is applicable. For the salmon Salmo salar five 
stanzas are described during ontogeny; the four inflections which delimit these stanzas are approximately coincident with the attainment of the eyed-egg stage, hatching, ossification and sexual maturity, with the greatest deviations from isosmetric growth in early ontogeny. Very early inflections, as well as those at about $30 \mathrm{~mm}$ length and at sexual maturity, are assumed to be of special importance in the determination of body form. MARTIN found no causal connection between body form and either rate of development or subsequent growth rate. He believes though that either of these processes may indirectly affect body form through their influences on body size at inflection. NETSCH \& WITT (1962), on the other hand, come to the conclusion that in the longnose gar Lepisosteus osseus rapid growth of subadult young is due in some degree to body shape. L. osseus, which have elongate, slender bodies, exhibited the largest daily gain in length.

\section{SUMMARY}

1. Spawning groups of the teleost Cyprinodon macularius kept at $28^{\circ} \mathrm{C}$ in airsaturated water of $35 \%$ salinity were allowed to spawn at intervals of 3 to 4 days. Their eggs were transferred 4 hours after fertilization into a variety of temperature-salinity combinations and the newly hatched young fixed within 60 minutes. The body form of these young was then examined by measuring 13 different length, depth and width dimensions.

2. All 13 dimensions vary as a function of the temperature and salinity conditions effective during incubation. The dimension versus temperature plot results in differently shaped curves in the three test salinities.

3. In fresh water, body length decreases above and below $32^{\circ}$ to $33^{\circ} \mathrm{C}$, while the various depth and width measurements increase. Maximum total length values are therefore correlated with minimum depth and width values; the body tends to become deeper and wider in the lowest and highest temperatures tested.

4. In $35 \%$ body length decreases progressively with increasing temperature, especially near the upper critical temperature $\left(34^{\circ}, 35^{\circ} \mathrm{C}\right)$. All depth and width dimensions measured tend to decrease more or less harmoniously; hence there is little change in body form (isometry).

5. In $70 \%$ body length decreases rapidly from $26^{\circ}$ to $28^{\circ} \mathrm{C}$ but changes little in the next higher temperature level $\left(31^{\circ} \mathrm{C}\right)$. All depth and width dimensions measured tend to change proportionally (often not quite as harmoniously as in $35 \%$ ).

6. It seems possible that the increasing degree of disharmony in the order $35 \%<$ $70 \%<$ fresh water is related to the fact that (a) all eggs tested were laid and fertilized in $35 \%$ and remained there for 4 hours before being transferred into the test salinities and $(b) 35 \%$ affords near optimum conditions for growth and reproduction. It seems possible that the structural consequences of exposure to the different incubation media may be different if spawning took place in fresh water or $70 \%$ instead of in $35 \%$. 
7. Body depth and width tend to increase with decreasing salinity, resulting in rounder fish in fresh water with less surface area per unit volume.

8. Body dimensions (length as well as depth and width) are significantly smaller in $70 \%$ than in fresh water or $35 \%$.

9. Changes in body dimensions of hatching fry may be related to the concomittant changes in the amounts of dissolved gases, especially $\mathrm{O}_{2}$, in the various temperature and salinity combinations employed.

10. Environmental effects during very early ontogeny are of paramount importance for the functional and structural properties of the individual and may modify its ecological capacities.

\section{ACKNOWLEDGMENTS}

It is a pleasure to adknowledge gratefully financial aids to the second named author by the National Research Council of Canada (1961) and the University of Toronto Advisory Committee on Scientific Research (1961). We would also like to thank Miss F. W. Crouse, who helped to prepare the manuscript and the Bundesernährungsministerium, Bonn, for making such help possible while the second named author was on a teaching and research leave at the Marine Biological Laboratory, Woods Hole, Massachusetts, USA (1964).

\section{LITERATURE CITED}

Baird, S. F. \& GIRARd, C., 1853. Descriptions of new species of fishes collected by Mr. J. H. Clark, on the U.S. and Mexican Boundary Survey, under Lt. Col. Jas. D. Graham. Proc. Acad. Nat. Sci. 6, 387-390.

BarLow, G. W., 1958a. Daily movements of desert pupfish, Cyprinodon macularitus, in shore pools of the Salton Sea, California. Ecology 39, 580-587.

- 1958b. High salinity mortality of desert pupfish, Cyprinodon macularizs. Copeia 3, $231-232$.

BLAXTER, J. H. S., 1957. The effect of temperature and other factors on myotome counts. Mar. Res. Scot., No. 1,16 pp.

- \& Hempex, G., 1961. Biologische Beobachtungen bei der Aufzucht von Heringsbrut. Helgol. Wiss, Meeresunters., 7, 260-283.

BoetTGer, C. R., 1950. Ein Beitrag zur Frage des Ertragens von Brackwasser durch Molluskenpopulationen. Hydrobiologia 2, 360-379.

DANNEVIG, A., 1950. The influence of the environment on number of vertebrae in plaice. Rep. Norweg: Fish. Mar. Invest. 9, 1-16.

GaBrieL, M. L., 1944. Factors affecting the number and form of vertebrae in Fundulus beteroclitus. J. exp. Zool. 95, 105-147.

GunTER, G., 1957. 'Temperature. In: Treatise on marine ecology and paleoecology; edited by J. W. Hedgreth. Geol. Soc. Am. Mem. No. 67, 159-184.

Harder, W., 1957. Die Darmlänge bei Clupeoiden von Fundorten verschiedener geographischer Breite. Année biol. 33, 171-177.

Hass, G., 1936. Variationsstatistische Untersuchungen an Proben von Gobius microps Kroyer aus der Kieler Bucht und der Schlei. Schr. Naturwe. Ver. Schl.-Holst. 21, 419-426.

- 1937. Variabilitätsstudien an Gobins niger L., Gobius minutus Pallas und Cottus scorpius L. Kieler Meeresforsch. 1, 279-321.

Feincke, F., 1881. Die Varietäten des Herings. T. 2. Vierter Ber. Comm. wiss. Unters. dtsch. Meere, Kiel, 1-86. 
HEMpex, G., 1953. Die Temperaturabhängigkeit der Myomerenzahl beim Hering (Clupea barengus L.). Naturwissenschaften 40, 467-468.

- \& BeAXter, J. H. S., 1961. Einfluß von Temperatur und Salzgehalt auf Myomerenzahl und Körpergröße von Heringslarven. Z. Naturf. 16b, 227-228.

Holliday, F. G. T. \& Blaxter, J. H. S., 1960. The effects of salinity on the developing eggs and larvae of the herring. J. Mar. biol. Ass. U.K, 39, 591-603.

HurBss, C. L., 1922. Variation in the number of vertebrae and other meristic characters of fishes correlated with the temperature of water during development. Am. Nat. 56, 360-372.

- 1926. The structural consequences of modifications of the developmental rate in fishes, considered in reference to certain problems of evolution. Am. Nat. 60, 57-81.

- 1934. Racial and individual variation in animals, especially fishes. Am. Nat. 68, 115-128.

ITAZAWA, Y., 1959. Influence of temperature on the number of vertebrae in fish. Nature, Lond. 183, 1408-1409.

Jordan, D. S., 1891. Relations of temperature to vertebrae among fishes. Proc. U.S. nat. Mus. $14,107-120$.

Kinne, O., 1956. Uber den Einfluß des Salzgehaltes und der Temperatur auf Wachstum, Form und Vermehrung bei dem Hydroidpolypen Cordylophora caspia (PALLAS), Athecata, Clavidae. I. Mitteilung über den Einfluß des Salzgehaltes auf Wachstum und Entwicklung mariner, brackischer und limnischer Organismen. Zool. Jb. (Physiol.) 66, 565-638.

- 1958a. Uber die Reaktion erbgleichen Coelenteraten-Gewebes auf verschiedene Salzgehaltsund Temperaturbedingungen. II. Mitteilung über den Einfluß des Salzgehaltes auf Wachstum und Entwicklung mariner, brackischer und limnischer Organismen. Zool. Jb. (Pbysiol.) $67,407-486$.

- 1958b. Adaptation to salinity variations - some facts and problems. In: Physiological Adaptation; edited by C. L. Prosser. Am. Physiol. Soc. Washington. D. C., 92-106.

- 1960. Growth, food intake, and food conversion in a euryplastic fish exposed to different temperatures and salinities. Pbysiol. Zoöl. 33, 288-317.

- 1962. Irreversible nongenetic adaptation. Comp. Biochem. Physiol. 5, 265-282.

- 1963a. Uber den Einfluß des Salzgehaltes auf verschiedene Lebensprozesse des Knochenfisches Cyprinodon macularius. Veröff. Inst. Meeresforsch. Bremerhaven, Sonderbd. Drittes meeresbiol. Symp., 49-66.

$-1963 \mathrm{~b}$. The effects of temperature and salinity on marine and brackish water animals. I. Temperature. Oceanogr. Mar. Biol. Ann. Rev. 1, 301-340.

- 1964. The effects of temperature and salinity on marine and brackish water animals. II. Salinity and temperature-salinity combinations. Oceanogr. Mar. Biol. Ann. Rev. 2, $281-339$.

- \& KINNE, E. M., 1962a. Effects of salinity and oxygen on developmental rates in a cyprinodont fish. Nature, Lond. 193, 1097-1098.

-, - 1962b. Rates of development in embryos of a cyprinodont fish exposed to different temperature-salinity-oxygen conditions. Can. J. Zool. 40, 231-253.

- \& SWEET, J. G., 1964. Die Umweltabhängigkeit der Körperform frischgeschlüpfter Cyprinodon macularis (Teleostei). Naturceissenschaften (in press).

Lindsey, C. C., 1954. Temperature-controlled meristic variation in the paradise fish Macropodus opercularis (L). Can. J. Zool. 32, 87-98.

- 1962. Experimental study of meristic variation in a population of three spine sticklebacks, Gasterosteus aculeatus. Can. J. Zool. 40, 271-312.

Marckmann, K., 1954. Is there any correlation between metabolism and number of vertebrae (and other meristic characters) in the sea trout (Salmo trutta trutta L.)? Medd. Kom. Danm. Fisk. Havundersog. 1, 1-9.

MarTIN, W. R., 1949. The mechanics of environmental control of body form in fishes. Univ. Toronto biol. Ser. No, 58, 1-92.

MrLleR, R. R., 1948. The cyprinodont fishes of the Death Valley system of eastern California and southwestern Nevada. Misc. Publ. Mus. Zool. Univ. Mich. No. 68, 1-155.

Möвrus, K. \& Heincke, F., 1883. Die Fische der Ostsee. Vierter Ber. Comm. wiss. Unters. dtsch. Meere, Kiel, 193-296. 
Molander, A. R. \& Molander-SwEdmark, M., 1957. Experimental investigations in plaice (Pleuronéctes platessa Linné). Inst. Mar. Res. Lysekill, Ser. Biol. Rep. No. 7, 3-45.

Moore, H. B., 1958. Marine ecology. John Wiley \& Sons, Inc., New York, 493 pp.

Morris, R. W. \& SCHEER, B. T., 1957. The relation of meristic characters in fishes to temperature and water movements. Année biol. 33, 159-161.

MotTLEY, C. McC., 1934. The effect of temperature during development on the number of scales in the Kamloops trout Salmo kamloops Jordan. Contr. Can. Biol. Fish. 8, 254-263.

- 1937. The number of yertebrae in trout (Salmo). J. biol. Bd. Can. 3, 169-176.

Netsch, N. F. \& WITT, A., Jr., 1962. Contributions to the life history of the longnose gar (Lepisosteus osseus) in Missouri. Transact. Am. Fish. Soc. 91, 251-262.

Pearse, A. S. \& Gunter, G., 1957. Salinity. In: Treatise on marine ecology and palaeoecology. I; edited by J. W. Hedgpetr. Geol. Soc. Am. Mem. No. 67, 129-157.

Remane, A., 1934. Die Brackwasserfauna. Verh. dtsch. zool. Ges. 36, 34-74.

- 1940. Einführung in die zoologische Obologie der Nord- und Ostsee (Teil Ia). In: Die Tierwelt der Nord- und Ostsee; edited by A. RemANE, Akademische Verlagsgesellschaf, Leipzig, 124 pp.

- \& SChlifPer, C., 1958. Die Biologie des Brackwassers. In: Die Binnengewässer; edited by A. Threnemann, Vol. XXII, E. Schweizerbart, Stuttgart, 348 pp.

Rounsefelu, G. A. \& DahLgren, E. H., 1932. Fluctuations in the supply of herring, Clupea pallasii, in Prince William Sound, Alaska. Bull. Bur. Fish. Wash. 47, 263-291.

Scнmid, J, 1917. Racial investigations. II. Constancy investigations continued. C. $r$. Trav. Lab., Carlsberg 14, 1-19.

- 1919a. Racial studies in fishes. II. Experimental investigations with Lebistes reticulatus (Peters) Regan. J. Genet. 8, 147-153.

- 1919b. Racial investigations. III. Investigations with Lebistes reticulatus (Peters) Regan. C. r. Trav. Lab., Carlsberg 14, 1-8.

- 1920. Racial investigations. V. Experimental investigations with Zoarces viviparous L. C. r. Trav. Lab., Carlsberg 14, 1-14.

- 1921. Racial investigations. VII. Annual fluctuations of racial characters in Zoarces viviparus L. C. r. Trav. Lab., Carlsberg 14, 1-24.

- 1930. Racial investigations. X. The Atlantic cod (Gadus callarias L.) and some local races of the same. C. r. Trav. Lab., Carlsberg 18, 1-72.

SchulTz, L. P., 1926. Temperature-controlled variation in the golden shiner, Notemigonus crysoleucas. Pap. Mich. Acad. Sci. 7, 417-432.

Segerstråle, S. G., 1957. Baltic Sea. In: Treatise on marine ecology and paleoecology. I; edited by J. W. Hedgpetr. Geol. Soc, Am. Mem. No. 67, 751-800.

Seymour, A. H., 1956. Effects of temperature upon young chinook salmon. Dissertation ( $\mathrm{Ph}$. D. Thesis), Univ. Washington, Seattle, $127 \mathrm{pp}$.

- 1959. Effects of temperature upon the formation of vertebrae and fin rays in young chinook salmon. Trans. Am. Fish. Soc. 88, 58-69.

TÅNING, Å. V., 1944. Experiments on meristic and other characters in fishes. I. On the influence of temperature on some meristic characters in sea-trout and the fixation-period of these characters. Medd. Kom. Danm. Fisk. Havundersøg. 11, 1-66.

- 1946. Stage of determination of vertebrae in teleostean fishes. Nature, Lond. 157, 594-595.

- 1950. Influence of the environment on number of vertebrae in teleostean fishes. Nature, Lond. 165, 28.

- 1952. Experimental study of meristic characters in fishes. Biol. Rev. 27, 169-193.

VladYkov, V. D., 1934. Environmental and taxonomic characters of fishes. Trans. Roy. Can. Inst. 20, 99-140. 